\title{
STUDIES ON EFFECT OF NUTRIENT AND IRRIGATION LEVELS ON GROWTH AND YIELD PARAMETERS, AND ON KAPAS YIELD OF COTTON IN SOUTHERN DRY ZONE OF KARNATAKA
}

PRAKASH, B. H, YOGANANDA, S. B, SHEKARA, B. G, PRAKASH, S. S \& VIJAY KUMAR, L Department of Agronomy, College of Agriculture, VC Farm, UAS, Bengaluru, India

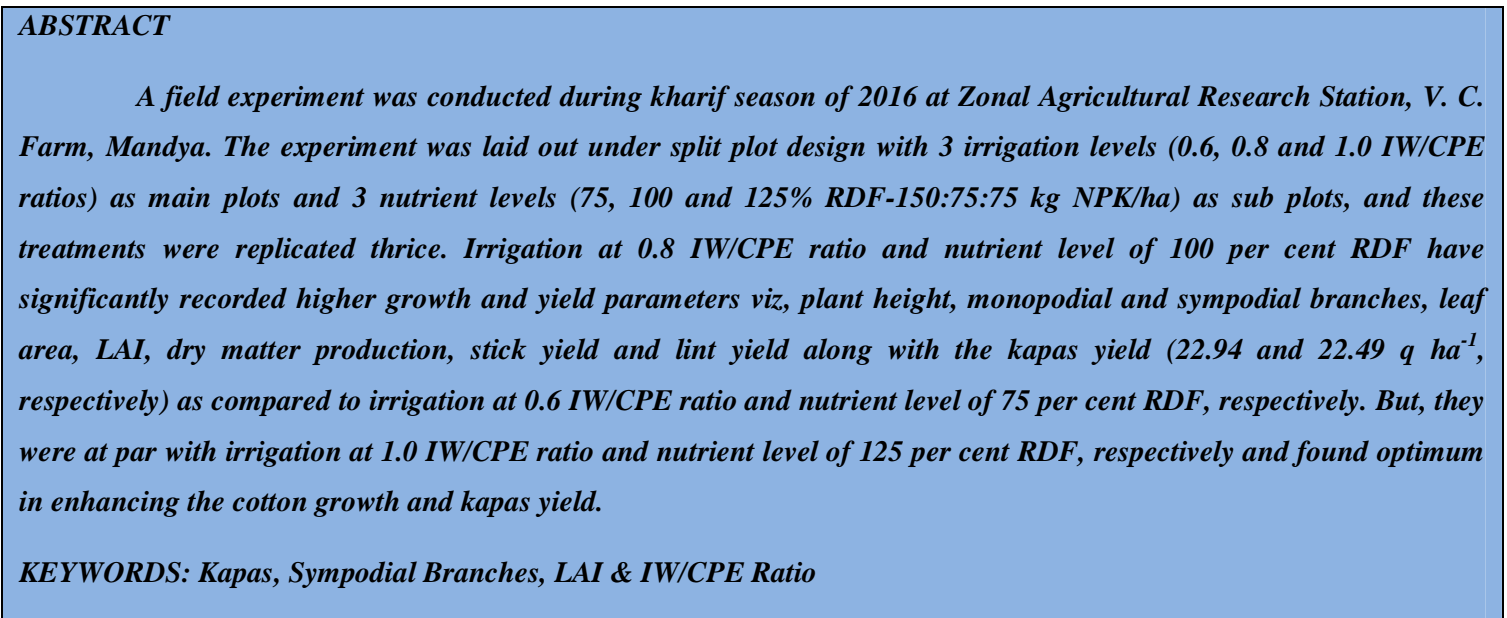

Received: Jun 29, 2017; Accepted: Jul 16, 2017; Published: Jul 20, 2017; Paper Id.: IJASRAUG201750

\section{INTRODUCTION}

Cotton is popularly called as "White Gold" and is considered as "King of fiber crops". It is an important cash crop of global significance, which plays a dominant role in the world agriculture and industrial economy. Cotton is an important raw material for the Indian textile industry and contributes at least 65 per cent of its requirements. India is the largest producer of cotton and contributes 25.4 per cent to the world cotton production. India has the largest area $(11.7 \mathrm{~m}$ ha) with 36.9 million bales production with an average productivity of $532 \mathrm{~kg}$ $\mathrm{ha}^{-1}$ (Anon, 2016). Gujarat is the leading producer (125 lakh bales) of cotton, followed by Maharastra (85 lakh bales) while, Tamil Nadu ranks first in productivity $(1214 \mathrm{~kg} / \mathrm{ha})$.

The productivity of cotton in our country is low since, 70 per cent of the cotton is grown under rainfed condition. The external supply of irrigation water to the cotton crop has increased the cotton yield tremendously as reported by Sankaranarayanan et al. (2004). They have obtained 20 to 25 per cent higher seed cotton yield under irrigated condition over unirrigated crop. Along with the supply of irrigation, nutrients application also helps in getting enhanced yield. Application of all the three nutrients had effect on lint yield although most of the response was attributed to $\mathrm{N}$ (all cultivars) and to some extent $\mathrm{P}$. The results for all quality factors suggest that $\mathrm{K}$ fertilization is a key to better quality (Kefyalew et al, 2007). The influence on optimum irrigation regime under different nutrients level in red sandy loamy soils of southern dry zone of Karnataka were revealed to be meager. Hence the present investigation is conducted to optimize the irrigation regime, nutrient levels and their interaction 
for higher kapas yield of cotton.

\section{MATERIALS AND METHODS}

The field experiment was conducted during kharif season of 2016, from June to December in red sandy loam soil at Zonal Agricultural Research Station, Vishweshwaraiah Canal Farm, Mandya. The soil of the experimental site was sandy loam in texture. The soil was neutral in soil reaction with a $\mathrm{pH}$ of 7.27 and normal in electrical conductivity ( 0.38 $\mathrm{dS} / \mathrm{m})$. The organic carbon content was 0.46 per cent and low in available $\mathrm{N}\left(210.54 \mathrm{~kg} \mathrm{ha}^{-1}\right)$, medium in available phosphorus (27.48 $\mathrm{kg} \mathrm{ha}^{-1}$ ) and available potassium $\left(152.20 \mathrm{~kg} \mathrm{ha}^{-1}\right)$. The experiment was laid out in split plot design with 3 irrigation levels (0.6, 0.8 and 1.0 IW/CPE ratios) as main plots and 3 nutrient levels (75, 100 and 125\% RDF-150:75:75 $\mathrm{kg} \mathrm{NPK/ha)} \mathrm{as} \mathrm{sub} \mathrm{plots,} \mathrm{and} \mathrm{these} \mathrm{treatments} \mathrm{were} \mathrm{replicated} \mathrm{thrice.}$

Cotton hybrid "Varalakshmi' (DCH-32) was used in the experiment sown at a spacing of $90 \mathrm{~cm} \times 60 \mathrm{~cm}$. The fertilizers were applied as per the treatments through soil application, in which 50 per cent of $\mathrm{N}$ and full dose of $\mathrm{P}$ and $\mathrm{K}$ were applied at as basal dose. Remaining 50 per cent of $\mathrm{N}$ was top dressed in two splits at 50 DAS (25\% N) and at 75 DAS $(25 \% \mathrm{~N})$. Irrigation was given by quantifying through water meter using the IW/CPE relation by fixing the IW (irrigation water) as $60 \mathrm{~mm}$ depth. Necessary plant protection measures were taken for the control of sucking pests like aphids, thrips and white flies.

\section{RESULTS AND DISCUSSIONS}

\section{Growth and Yield Parameters}

The experimental data (Table 1) indicates that, irrigation at 1.0 IW/CPE ratio was recorded significantly higher plant height at 150 DAS (154.47 cm), monopodial and sympodial branches (2.35 and 20.11/plant, respectively) at harvest, dry matter production plant $^{-1}$ at 120 DAS (376.21 g/plant) over irrigation at $0.6 \mathrm{IW} / \mathrm{CPE}$ ratio $(136.28 \mathrm{~cm}, 1.55$ and 14.01/plant and $296.19 \mathrm{~g} /$ plant, respectively). However, it was at par with irrigation at 0.8 IW/CPE ratio (150.33 cm, 2.19 and 17.54/plant and $347.47 \mathrm{~g} / \mathrm{plant}$, respectively). Among the different nutrient levels, 125 per cent RDF was recorded significantly higher plant height at 150 DAS $(150.00 \mathrm{~cm})$, monopodial and sympodial branches $(2.27$ and 19.23/plant, respectively) at harvest, dry matter production plant ${ }^{-1}$ at 120 DAS $(372.27 \mathrm{~g} / \mathrm{plant})$ over 75 per cent of RDF (135.35 $\mathrm{cm}$, 1.77 and 14.81/plant and 299.18 g/plant, respectively). However, it was at par with 100 per cent of RDF (145.73 cm, 2.06 and 17.63/plant and $348.42 \mathrm{~g} /$ plant, respectively). The data presented in Table 2 indicates that the irrigation at $1.0 \mathrm{IW} / \mathrm{CPE}$ ratio was recorded significantly higher leaf area at 120 DAS $\left(18521.85 \mathrm{~cm}^{2} /\right.$ plant), leaf area index at 120 DAS (3.43) and stick yield (33.81 q/ha) over irrigation at 0.6 IW/CPE ratio (13914.53 cm²/plant, 2.58 and 29.24 q/ha, respectively). However, it was at par with irrigation at $0.8 \mathrm{IW} / \mathrm{CPE}$ ratio $\left(17002.41 \mathrm{~cm}^{2} /\right.$ plant, 3.15 and $32.68 \mathrm{q} / \mathrm{ha}$, respectively).

Among the different nutrient levels, 125 per cent RDF ratio was recorded significantly higher leaf area at 120 DAS (17888.29 $\mathrm{cm}^{2} /$ plant), leaf area index at 120 DAS (3.31) and stick yield (33.17 q/ha) over 75 per cent RDF (14780.44 $\mathrm{cm}^{2} /$ plant, 2.74 and $\left.30.31 \mathrm{q} / \mathrm{ha}\right)$. However, it was at par with 100 per cent of RDF $\left(16700.05 \mathrm{~cm}^{2} / \mathrm{plant}, 3.11\right.$ and 32.12 $\mathrm{q} / \mathrm{ha}$ ). This was due to higher frequency of irrigation, which led to better availability and uptake of nutrients as well as their partition to different parts.

These results are in line with the findings of Srinivasan and Aananthi (2017), Yang et al. (2015) and Ghonganeet al. (2009). Increase in growth attributes was also due to higher quantity of nutrients coupled with good available moisture leading to better uptake and partition. In addition, nitrogen has crucial role in cell division and elongation there by 
increased the plant height. Phosphorus might have influenced better root growth there by increased uptake of nutrients and water. Better phosphorus management helps in diversion of plant metabolites towards the developing buds, flowers and bolls, and also the translocation of more photosynthates towards the sink and consequent development of yield attributes as reported by Seemaet al. (2012). Higher quantity of nutrient supply at the initial stages is also one of the reasons for enhanced growth parameters. These results also agree with the findings of Gundluret al. (2013), Ghonganeet al. (2009).

There was no significant difference in plant height, monopodial branches, sympodial branches and dry matter production due to combined effect of nutrient and irrigation levels. These results are in line with the findings of Gundluret al. (2013).

\section{Kapas and Lint Yield}

Different nutrient and irrigation levels had a significant effect on kapas and lint yield of cotton (Table 2). Irrigation at 1.0 IW/CPE ratio was recorded significantly higher kapas and lint yield of cotton (24.37 and 8.69 q/ha, respectively) over irrigation at 0.6 IW/CPE ratio (15.91 and $5.25 \mathrm{q} / \mathrm{ha}$, respectively). However, it was at par with irrigation at $0.8 \mathrm{IW} / \mathrm{CPE}$ ratio (22.94 and $8.12 \mathrm{q} / \mathrm{ha}$, respectively). Among the different nutrient levels, 125 per cent RDF was recorded significantly higher kapas and lint yield of cotton (23.55 and 8.35 q/ha, respectively) over 75 per cent RDF (17.18 and 5.83, respectively). However, it was at par with 100 per cent of RDF (22.49 and 7.88 q/ha, respectively). This was due to increased growth parameters, yield attributes and dry matter production as well as its partition to different parts due to combined effect of N, P and K with frequent irrigations. Higher sympodial branches leading to higher boll number and boll weight might have enhanced seed cotton yield. The leaf growth continued even at boll development stage and higher dry matter accumulation in the fruiting bodies at the later stages of the crop growth were also the reason for higher yield. These results are in conformity with the findings of Deepa and Aladakatti (2016), Amandeepet al. (2015), Gundluret al. (2013).

Table 1: Effect of Nutrient and Irrigation Levels on Plant Height, Monopodialbranchs, Sympodial Branches and Dry Matter Production

\begin{tabular}{|c|c|c|c|c|}
\hline \multirow[b]{2}{*}{ Treatment } & \multicolumn{4}{|c|}{ Parameters } \\
\hline & $\begin{array}{c}\text { Plant } \\
\text { Height } \\
(\mathrm{Cm}) \text { at } 150 \\
\text { DAS }\end{array}$ & $\begin{array}{c}\text { Monopodial } \\
\text { Branches Plant } \\
1 \text { at Harvest }\end{array}$ & $\begin{array}{c}\text { Sympodial } \\
\text { Branches Plant }^{-1} \text { at } \\
\text { Harvest }\end{array}$ & $\begin{array}{l}\text { Dry Matter } \\
\text { Production }^{-1}(G) \text { at } \\
\text { Plant }^{-1} \text { (G) } \\
120 \text { DAS }\end{array}$ \\
\hline \multicolumn{5}{|l|}{ Irrigation levels } \\
\hline $\begin{array}{l}\mathrm{I}_{1}: \quad \mathrm{IW} / \mathrm{CPE}= \\
0.6\end{array}$ & 136.28 & 1.55 & 14.01 & 296.19 \\
\hline $\begin{array}{l}\mathrm{I}_{2}: \quad \mathrm{IW} / \mathrm{CPE}= \\
0.8\end{array}$ & 150.33 & 2.19 & 17.54 & 347.47 \\
\hline $\begin{array}{l}\mathrm{I}_{3:} \mathrm{IW} / \mathrm{CPE}= \\
1.0\end{array}$ & 154.47 & 2.35 & 20.11 & 376.21 \\
\hline SEm. \pm & 1.97 & 0.06 & 0.68 & 7.97 \\
\hline C.D. @ 5\% & 7.73 & 0.23 & 2.65 & 31.21 \\
\hline \multicolumn{5}{|l|}{ Nutrient levels } \\
\hline $\mathrm{F}_{1}: 75 \% \mathrm{RDF}$ & 135.35 & 1.77 & 14.81 & 299.18 \\
\hline $\mathrm{F}_{2}: 100 \% \mathrm{RDF}$ & 145.73 & 2.06 & 17.63 & 348.42 \\
\hline $\mathrm{F}_{3}: 125 \% \mathrm{RDF}$ & 150.00 & 2.27 & 19.23 & 372.27 \\
\hline SEm. \pm & $\mathbf{1 . 8 5}$ & 0.07 & 0.66 & 7.23 \\
\hline C.D. @ 5\% & 7.26 & 0.26 & 2.58 & 28.31 \\
\hline \multicolumn{5}{|c|}{ Irrigation levels $\times$ Nutrient levels } \\
\hline SEm. \pm & 3.04 & 0.08 & 0.84 & 10.38 \\
\hline C.D. @ 5\% & NS & NS & NS & NS \\
\hline
\end{tabular}


Note: DAS: Days after sowing, IW: Irrigation water, CPE: Cumulative pan evaporation,

RDF: Recommended dose of fertilizers (150:75:75 Kg NPK/ha)

Table 2: Effect of Nutrient and Irrigation Levels on Leaf Area, Leaf Area Index (LAI), Stick Yield, Lint Yield and Kapas Yield

\begin{tabular}{|c|c|c|c|c|c|}
\hline \multirow[b]{2}{*}{ Treatment } & \multicolumn{5}{|c|}{ Parameters } \\
\hline & $\begin{array}{c}\text { Leaf area } \\
\left(\mathrm{cm}^{2} / \text { plant }\right) \text { at } \\
120 \text { DAS }\end{array}$ & $\begin{array}{c}\text { LAI at } 120 \\
\text { DAS }\end{array}$ & Stick yield (q/ha) & $\begin{array}{c}\text { Kapas } \\
\text { yield(q/ha) }\end{array}$ & $\begin{array}{l}\text { Lint yield } \\
\text { (q/ha) }\end{array}$ \\
\hline \multicolumn{6}{|l|}{ Irrigation levels } \\
\hline $\mathrm{I}_{1}: \mathrm{IW} / \mathrm{CPE}=0.6$ & 13914.53 & 2.58 & 29.24 & 15.91 & 5.25 \\
\hline $\mathrm{I}_{2}: \mathrm{IW} / \mathrm{CPE}=0.8$ & 17002.41 & 3.15 & 32.68 & 22.94 & 8.12 \\
\hline $\mathrm{I}_{3:} \mathrm{IW} / \mathrm{CPE}=1.0$ & 18521.85 & 3.43 & 33.81 & 24.37 & 8.69 \\
\hline SEm. \pm & 743.85 & 0.14 & $\mathbf{0 . 7 0}$ & $\mathbf{0 . 4 3}$ & 0.21 \\
\hline C.D. @ 5\% & 2911.53 & 0.54 & 2.73 & 1.69 & 0.81 \\
\hline \multicolumn{6}{|l|}{ Nutrient levels } \\
\hline $\mathrm{F}_{1}: 75 \% \mathrm{RDF}$ & 14780.44 & 2.74 & 30.31 & 17.18 & 5.83 \\
\hline $\mathrm{F}_{2}: 100 \% \mathrm{RDF}$ & 16770.05 & 3.11 & 32.12 & 22.49 & 7.88 \\
\hline $\mathrm{F}_{3}: 125 \% \mathrm{RDF}$ & 17888.29 & 3.31 & 33.17 & 23.55 & 8.35 \\
\hline SEm. \pm & 476.52 & 0.09 & 0.39 & 0.83 & 0.25 \\
\hline C.D. @ 5\% & 1865.16 & 0.35 & 1.51 & 3.25 & 0.97 \\
\hline \multicolumn{6}{|c|}{ Irrigation levels $\times$ Nutrient levels } \\
\hline SEm. \pm & 1161.70 & 0.22 & $\mathbf{0 . 8 3}$ & 2.57 & $\mathbf{0 . 8 5}$ \\
\hline C.D. @ 5\% & NS & NS & NS & NS & NS \\
\hline
\end{tabular}

Note: DAS: Days after sowing, IW: Irrigation water, CPE: Cumulative pan evaporation,

RDF: Recommended dose of fertilizers (150:75:75 Kg NPK/ha)

\section{CONCLUSIONS}

The experimental data revealed that irrigating the cotton at IW/CPE ratio of 0.8 was found optimum and recorded significantly higher seed cotton yield (22.94 q/ha) similar to that of IW/CPE ratio of 1.0 and application of 100 per cent RDF (150:75:75 kg NPK/ha) was found optimum and recorded significantly higher seed cotton yield (22.49 q/ha) similar to that of 125 per cent RDF.

\section{REFERENCES}

1. Amandeep, S. B, Sarlach, R. S. and Rathore, P. (2015).Response of desicotton (GossypiumarboreumL.) hybrids to spacing and fertilizer levels under irrigated conditions. Journal of Cotton Research and Development,29(1): 79-80

2. Anonymous (2016).www.statista.com

3. Deepa, G. S. andAladakatti, Y. R. (2016).Effect of nutrient levels and split application of nitrogen and potassium on yield, economics and fibre quality parameters of interspecific Bt cotton. Journal of Farm Science,29(2): 203-207

4. Ghongane, S. B, Yeledhalli, N. A, Ravi, M.V, Patil, B.V, Desai, B. K. andBeledhadi, R. V. (2009). Effect of fertilizer and irrigation levels on growth, yield and quality of transgenic bt cotton in deep vertisols. Karnataka Journal Agricultural Sciences,22(4): 905-908

5. Gundlur, S. S, Rajkumara, S, Neelakanth, J. K, Ashoka, P. andKhot, A. B. (2013).Water and nutrient requirement of Btcotton under vertisols of Malaprabha command. Karnataka Journal Agricultural Sciences,26(3): 368-371

6. Kefyalew, G, Roger, K. T, Kyle, W. F, Randal, K. B. and William, R. R. (2007).Cotton lint yield and quality as affected by 


\section{on Kapas Yield of Cotton in Southern Dry Zone of Karnataka}

applications of N, P, and K fertilizers. Journal of Cotton Science, 11:12-19

7. Sankaranarayanan, K, Nalayini, P. and Praharaj, C. S. (2004). Agronomic requirements of Bt cotton hybrid in relation to plant densities and fertilizer requirement. International Symposium onStrategies for Sustainable Cotton Production - A Global Vision, University of Agricultural Sciences, Dharwad. 23-25

8. Seema, S,Ahlawat, I. P. S. and Rana, D. S. (2012). Effect of phosphorus sources and levels on Bt-cotton (Gossypiumhirsutum) based intercropping systems. Indian Journal of Agronomy,57(3): 235-240

9. Srinivasan, G. and Aananthi, N. (2017). Effect of moisture stress management practices on growth, yield and quality of hirsutumcotton. Journal of Cotton Research and Development,31(1): 82-86

10. Yang, C, Luo, Y, Sun, L. and Wu, N. 2015. Effect of deficit irrigation on the growth, water use characteristics and yield of cotton in arid northwest China. Pedosphere. 25(6): 910-924 
